Z Badań nad Książką i Księgozbiorami Historycznymi 2019. T. specjalny: Dla Niepodległej The Studies into the History of the Book and Book Collections 2019. Special issue: For an Independent Poland

Elżbieta Pokorzyńska

https://doi.org/10.33077/uw.25448730.zbkh.2020.205

Uniwersytet Kazimierza Wielkiego w Bydgoszczy

e.pokorzynska@ukw.edu.pl

ORCID 0000-0001-7918-8226

\title{
Introligatorstwo warszawskie w przededniu II wojny światowej
}

\begin{abstract}
Warsaw bookbinding before World War II

In liberated Poland, new craft law reduce privilege of traditional guild to conduct licensure exam. Despite, effects of Great Depresion took a toll on Poland, the number of bookbinding workshops was high. In the end of decade it was about 300, and the number of workers higher than 1000 . Even bookbinders made their traditional works, such as handbookbindings and fancy goods, they made publishing bindings much more often, up to $10 \%$ of all their works.
\end{abstract}

Key words: history of bookbinding in 20 C. - Warsaw bookbinders.

Słowa kluczowe: historia introligatorstwa XX w. - introligatorzy warszawscy.

„Z Badań nad Książką i Księgozbiorami Historycznymi” - Udział zagranicznych recenzentów w ocenie publikacji; Stworzenie anglojęzycznej wersji wydawniczej publikacji; Digitalizacja tomów archiwalnych rocznika w celu zapewnienia otwartego dostępu do nich przez Internet oraz wdrożenie i utrzymanie cyfrowej platformy redakcyjnej - zadanie finansowane w ramach umowy nr 653/P-DUN/2019 ze środków Ministra Nauki i Szkolnictwa Wyższego przeznaczonych na działalność upowszechniającą naukę. 
Badania nad introligatorstwem warszawskim utrudnia brak podstawowych materiałów źródłowych, tj. archiwalnych dokumentów miejskich, organizacji zawodowych i zakładów rzemieślniczych, zniszczonych lub zagubionych podczas II wojny światowej. Z tego względu studia oparte są na materiałach drukowanych: prasie oraz dokumentach życia społecznego, a także efektach pracy środowiska introligatorskiego, przede wszystkim oprawionych egzemplarzach książek.

Temat ujęty w niniejszym opracowaniu był już fragmentarycznie omówiony w mojej niepublikowanej pracy doktorskiej $Z$ dziejów introligatorstwa warszawskiego $X I X i$ 1. polowy $X X$ wieku ${ }^{1}$. Sztuka introligatorska warszawskich mistrzów była przedmiotem rozważań Stanisława Rowińskiego ${ }^{2}$. Opracowania lub przynajmniej biogramu encyklopedycznego w Stowniku pracowników ksią̇ki polskiej doczekało się kilku warszawskich introligatorów epoki międzywojennej: Jan Recmanik, Zofia Dębicka, Franciszek Joachim Radziszewski, Bonawentura Lenart, Władysław Grabowski, Wanda Michalska, Włodzimierz Dippel, Bolesław Zjawiński, Zdzisław Szafranek.

Zagadnienie opraw wydawniczych było podejmowane przez Janusza Dunina, Jana Strausa, Piotra Rypsona oraz Janusza Tondela ${ }^{3}$, jednak autorzy ci koncentrowali się na artystycznej stronie okładek, głównie broszurowych, nie wdając się w tematykę introligatorską.

\section{Status prawny}

Przez ponad sto lat podstawą prawną działalności rzemieślniczej była wydania w 1816 r. Ustawa o Zgromadzeniach. Według tego prawa przynależność do cechu była dobrowolna, a w gestii zrzeszenia pozostawiono naukę zawodu i egzaminowanie (czyli wyzwalanie czeladników) oraz działalność samopomocową. W ciągu stulecia wprowadzono wiele zarządzeń uzupełniających, najważniejszym było rozporządzenie z 1845 r. dające możność uzyskania

1 E. Pokorzyńska, Z dziejów introligatorstwa warszawskiego XIX i 1. połowy XX wieku, praca doktorska, prom. E. Różycki, Katowice Uniwersytet Śląski 2009.

2 S. Rowiński, Europejskość i polskość w oprawach wybitnych mistrzów pierwszej polowy $X X$ wieku $w$ Polsce. Reminiscencje warszawskie, [w:] Introligatorstwo warszawskie, Warszawa [2005], Sesje Varsavianistyczne, t. 15, s. 59-61.

J. Dunin, Rozwój cech wydawniczych polskiej książki literackiej XIX-XX wieku, Łódź 1982, Acta Universitatis Lodziensis. Folia Scientiarum Artium et Librorum, 4, s. 120-133; tenże, Okładka i obwoluta jako komunikat. Wprowadzenie do problematyki, [w:] Sztuka ksiazki. Historia - teoria - praktyka, red. M. Komza, Wrocław 2003, Acta Universitatis Wratislaviensis, t. 24, s. 81-90; H. Makowska, J. Straus, Sztuka polskiej książki literackiej 1918-1939. Katalog wystawy, Warszawa, maj-sierpień 1986, Warszawa 1986; J. Straus, Cięcie. Fotomontaż na oktadkach w międzywojennej Polsce, Warszawa 2014; P. Rypson, Nie gęsi. Polskie projektowanie graficzne 1919-1949, Kraków 2011; J. Tondel, Okładki ksiązek i czasopism z okresu Młodej Polski oraz międzywojnia od Wyspiańskiego do Strzemińskiego w Bibliotece Uniwersyteckiej w Toruniu, Toruń 2019. 
magistrackiego pozwolenia na prowadzenie zakładu na równi z mistrzami cechowymi (tzw. konsens), z którego korzystali przede wszystkim rzemieślnicy żydowscy ${ }^{4}$.

Odrodzone państwo polskie zmagało się z koniecznością ujednolicenia prawa, dla rzemiosła wprowadzono rozwiązania, obowiązujące już wcześniej w zaborze pruskim. Nowe prawo weszło w życie w 1927 r., w drodze rozporządzenia prezydenta Rzeczypospolitej o prawie przemysłowym ${ }^{5}$. Przepisy dotyczące rzemiosła znalazły się w IX dziale tego rozporządzenia. Do prowadzenia działalności rzemieślniczej wymagano potwierdzonego dokumentem wykształcenia, którym był dyplom mistrzowski lub dyplom czeladniczy wraz z potwierdzeniem trzyletniej praktyki w zawodzie. Powołano do istnienia Izby Rzemieślnicze, przenosząc na nie większość zadań spełnianych dotychczas przez cechy, takich jak powoływanie komisji egzaminacyjnych, wystawianie dokumentów, prowadzenie kas i funduszy zapomogowych.

Wielu rzemieślników nie posiadało dyplomu zawodowego niezbędnego do zarejestrowania zakładu, dlatego musieli te braki uzupełnić. Cechowy monopol na kształcenie i wyzwalanie czeladników zlikwidowano, zezwalając na przeprowadzanie egzaminów w wojsku, w szkołach zawodowych, także niektóre świadectwa szkolne miały być równoważne z dyplomem czeladniczym ${ }^{6}$.

Nowe prawo przemysłowe spotkało się z niechęcią środowiska. Wskutek zabiegów lobby rzemieślniczego doszło do nowelizacji przepisów w kierunku wzmocnienia cechów, powierzono im reprezentowanie interesów zawodowych i gospodarczych przez prawo do zawiązywania związków cechów, zezwolono na tworzenie spółek i spółdzielni dla organizacji zaopatrzenia i zbytu a nawet wspólnej produkcji ${ }^{7}$.

Obciążenia podatkowe regulował wprowadzony w 1925 r. państwowy podatek przemysłowy; dla rzemiosła jedyną formą płatności był ryczałt opłacany w drodze wykupu corocznych świadectw przemysłowych, zaś wysokość opłaty zależała od liczby zatrudnionych oraz obrotów zakładu.

${ }^{4}$ Z dziejów rzemiosła warszawskiego, red. B. Grochulska, W. Pruss, Warszawa 1983, s. 305309, 350-362, 388-411; Ustawa zgromadzeń rzemieślniczych, „Gazeta Przemysłowo-Rzemieślnicza” 1905, nr 16, s. 126.

5 Rozporządzenie Prezydenta Rzeczypospolitej z dnia 7 czerwca 1927 r. o prawie przemysłowym, Dz. U. 1927, nr 53, poz. 468, s. 697-720, [online] http://prawo.sejm.gov.pl/isap.nsf/download. xsp/WDU19270530468/O/D19270468.pdf [dostęp 16.12.2019].

6 Tamże; M.M., Introligatorstwo w świetle polskiej ustawy przemysłowej, „Polska Gazeta Introligatorska" 1929, nr 11, s. 143-144; Kto może otworzyć warsztat rzemieślniczy, tamże 1930, nr 2, s. $15-16$; nr 3, s. 44-46.

7 J. Świerzewski, Rzemiosło warszawskie w latach II Rzeczypospolitej, [w:] Z dziejów rzemiosta warszawskiego..., s. 480-483.

8 Ustawa z dnia 15 lipca 1925 r. o państwowym podatku przemysłowym, Dz. U. 1925, nr 79, poz. 550, [online] http://prawo.sejm.gov.pl/isap.nsf/download.xsp/WDU19250790550/O/ D19250550.pdf [dostęp 16.12.2019]. 
Introligatornie działające przy drukarniach podlegały innym zasadom, gdyż drukarstwo zostało uznane za przemysł i nie podlegało Izbie Rzemieślniczej. Dlatego prawo egzaminowania $\mathrm{w}$ zawodzie introligatorskim uzyskało także Stowarzyszenie Zakładów Graficznych.

\section{Socjotopografia warszawskich zakładów introligatorskich}

Pod koniec lat 30. XX w. w Warszawie istniało ok. 300 zakładów introligatorskich działających na podstawie karty rzemieślniczej. Wśród właścicieli zakładów większość (2/3) stanowili Żydzi. Zatrudnionych w zawodzie było około tysiąca osób. Koniec lat 30. przyniósł znaczną poprawę kondycji branży po kryzysowym roku 1932, kiedy to działało tylko 225 zakładów zatrudniających 450 osób ${ }^{9}$. Nadto istniała nieznana liczba warsztatów działających przy drukarniach, bibliotekach, szkołach i urzędach.

W rozmieszczeniu zakładów introligatorskich można dostrzec pewne prawidłowości. Zakłady rzemiosła artystycznego ulokowane były wzdłuż traktu królewskiego, w rejonie Krakowskiego Przedmieścia, Nowego Światu i ulic przyległych. Największe zagęszczenie tradycyjnych zakładów rzemieślniczych występowało w rejonie ulic Nowy Świat - Marszałkowska - Aleje Jerozolimskie. Liczne zakłady manufakturowo-przemysłowe, zajmujące się wyrobem galanterii i oprawą wydawniczą znajdowały się w tzw. zachodniej dzielnicy przemysłowej, na zachód od ul. Marszałkowskiej, sąsiadowały z zakładami żydowskimi, które mieściły się w dzielnicy północno-zachodniej, w której okupanci później utworzą getto ${ }^{10}$.

Zdecydowana większość introligatorni była zakładami małymi, według danych z roku 1933, na 291 zakładów aż 234 wykupywały świadectwa ostatniej, ósmej kategorii, co oznacza że liczba pracujących w nich, wraz właścicielem i członkami rodziny nie przekraczała 4 osób. Koszt najtańszego świadectwa wynosił 15 zł. W dalszej kolejności zakładów kategorii siódmej było 35 (4-7 pracowników), szóstej - 12, piątej - 7, a czwartej - 3. Wśród nich była

$9 \quad$ Sprawozdanie Izby Rzemieślniczej w Warszawie za 1938 r., Warszawa 1939, s. 90-91; Sprawozdanie Izby Rzemieślniczej w Warszawie za 1932 r., Warszawa 1933, s. 86.

10 Ustaleń dokonano $\mathrm{w}$ drodze nałożenia na plan miasta adresów zakładów introligatorskich znajdujących się w książkach adresowych i telefonicznych (ok. 100 adresów): Księga adresowa Polski. Przemystu, handlu, finansów, szkolnictwa, wolnych zawodów i organizacji społecznych, wyd. 5, Warszawa 1938, s. 191-193; Spis abonentów sieci Telefonicznej m.st. Warszawy P.A.S.T. i Warszawskiej Sieci Okręg P.P.T.T. Rok 1939/1940, Warszawa 1939-1940, s. 571; Warszawski skorowidz branżowy na rok 1936-1937. Obejmuje: finanse, przemyst, handel, rzemiosto, wolne zawody, [zest. i oprac. J. Schranz], Warszawa [ok. 1937], s. 238-239; Chrześcijańska Warszawa. T. 1: Księga informacyjna polskiego przemystu, finansów, handlu, rzemiosła, szkolnictwa, prasy, wolnych zawodów, instytucyj państwowych, samorzadowych i prywatnych, organizacyj gospod., spot., kultur., oświat., naukowych, dobroczynnych., zawodowych, i t.p. miasta stotecznego Warszawy, pod red. S. Kwiatkowskiego, Warszawa 1939, s. 129-130. 
Introligatornia Artystyczna W. Michalskiej, której wysokość podatku w roku 1938 wyniosła 1100 zł. Powstały w roku 1939 zakład Mieczysława Wołłowicza musiał być naprawdę duży, bowiem został zaliczony do kategorii pierwszej, a taką kategorię uzyskiwały fabryki zatrudniające ponad 1000 osób ${ }^{11}$.

Do największych zakładów branży introligatorskiej należały wytwórnie ksiąg handlowych (Wenancjusza Miernickiego, Józefa Leśniewskiego), składające się z działu zajmującego się oprawianiem ksiąg oraz drukarni. Pod względem zatrudnienia największe były fabryki wytwarzające opakowania, pudełka i różne wyroby galanteryjne. Brak danych z końca lat międzywojennych można rekompensować źródłami z lat 20. według których fabryki pudełek zatrudniały: A. Ruppa 90, Tadeusza Pugeta 60, a W. Roszkowskiego 50 pracowników. Dużymi zakładami były fabryki albumów ze stanem zatrudnienia: H. Onassa -38 i Józefa Gelbarda - 15. Wśród introligatorni rzemieślniczych, zajmujących się oprawianiem książek największe były zakłady B. Zjawińskiego, spółki Wincentego Drawdzika i Aleksandra Mościckiego, Jana Flisińskiego oraz Władysława Tymińskiego, zatrudniające po około 30 pracowników ${ }^{12}$.

\section{Organizacje zawodowe}

Główną organizacją rzemieślniczą był cech, w strukturach Izb Rzemieślniczych introligatorstwo włączono do grupy rzemiosł skórzanych.

W odpowiedzi na zadania postawione przez nowe prawo przemysłowe, najważniejszym zadaniem cechu stało się przeprowadzanie egzaminów mistrzowskich i czeladniczych. Ze względu na duże potrzeby w zakresie nadawania tytułów zawodowych wśród rzemieślników żydowskich środowisko to utworzyło własny, równoległy cech introligatorski i w okresie kilkunastu lat w Warszawie istniały dwa cechy introligatorskie: tzw. chrześcijański oraz żydowski.

Po okresie aktywnej działalności, której apogeum miało miejsce w końcu XIX w., cech chrześcijański popadł w stagnację, ograniczając się do załatwiania niezbędnych, bieżących spraw ${ }^{13}$. W związku z tym, że przynależność

11 Sprawozdanie Izby Rzemieślniczej w Warszawie za 1933 r., Warszawa 1934, s. 82; Archiwum Biblioteki Publicznej m. st. Warszawy 341/3, k. 84, Odpis świadectwa przemysłowego Introligatorni Artystycznej; M. Wojewódzki, W tajnych drukarniach Warszawy 1939-1944. Wspomnienia, Warszawa 1976, s. 206; Wszelkie przedsiębiorstwa przemystowe nie wymienione w poprzednich ustepach, tudzież zajęcia rzemieślnicze, rękodzielnicze, dorożkarstwo i furmaństwo, „Kalendarz Skarbowy na rok 1936” 1935, s. 815-816. W 1939 r. nastąpiła zmiana prawa podatkowego, podatek przemysłowy zastąpiono podatkiem obrotowym.

12 Księga adresowa przemystu, handlu i finansów, oprac. A.R. Sroka, Warszawa 1926, poz. 18268-18356.

13 I. Kozłowski, Introligatorstwo polskie $w$ dobie obecnej, „Przegląd Graficzny, Wydawniczy i Papierniczy" 1939, nr 15/16, s. 151-153. 
do cechów nie była obowiązkowa, na ok. 300 warszawskich zakładów introligatorskich do cechu należeli pracownicy tylko ok. $30^{14}$. Cech był kierowany przez W. Miernickiego. Funkcję starszego cechu odziedziczył po swym ojcu Ludwiku, który przewodził cechowi w latach 1899-1921. Wenancjusz objął ją w roku 1924 i pełnił nieprzerwanie do wojny. W końcu lat 30. siedzibą cechu był jego zakład przy ul. Leszno 92, tam zapewne przechowywano insygnia, dokumenty i archiwum cechowe. Wydaje się, że cechowy skarb spłonął w 1939 roku ${ }^{15}$, dlatego brak źródeł informacji o działalności cechu w tym okresie, nieznany jest skład jego członków.

Cech warszawski zorganizował w 1931 r. Pierwszy Ogólnopolski Zjazd Przedstawicieli Zawodu Introligatorskiego ${ }^{16}$, który zgromadził ok. 80 uczestników z całego kraju. Przedmiotem obrad była konsolidacja środowiska oraz walka z nieuczciwą konkurencją w postaci warsztatów działających w więzieniach, biurach, szkołach. Na zjeździe zawiązano Związek Cechów Introligatorskich RP., jego prezesem został B. Zjawiński, podstarszy cechu warszawskiego ${ }^{17}$. Relację ze zjazdu zamieszczono na łamach poznańskiej „Polskiej Gazety Introligatorskiej"18.

Cechowi żydowskiemu, zwanemu Cechem Zrzeszonych Introligatorów m.st. Warszawy przewodniczył Majer Reisenblatt. W roku 1933 cech liczył 67 członków, miał siedzibę przy Bielańskiej 7, później przy Lesznie 52/5 (w lokalu Centralnego Związku Rzemieślników Żydów w Polsce), a w 1938 r. przy Nowiniarskiej $6^{19}$.

Własne organizacje mieli także pracownicy introligatorscy: czeladnicy skupiali się w Sekcji Introligatorów Zjednoczenia Pracowników Rzemieślniczych Rzeczypospolitej Polskiej w Warszawie ${ }^{20}$, robotnicy w Sekcji Introligatorów

14 Jedyna $\mathrm{z}$ tego okresu informacja dotycząca stanu cechu introligatorskiego pochodzi z roku 1925: (t), Nasze rzemiosła. Ankieta „Gazety Porannej”. Polscy introligatorzy. (Rozmowa z panem W. Miernickim, starszym zgromadzenia introligatorów), „Gazeta Poranna” 1925, nr 117, s. 7.

15 W roku 1950 Cech Introligatorów ufundował sztandar w miejsce dawnego, który spłonął w 1939 r.; informacja za: Warszawski Cech Introligatorów, 1950 rps, Akt erekcyjny.

16 De facto był to zjazd drugi po odbytym w 1929 r. Zjeździe Mistrzów Introligatorskich w Poznaniu, mającym miejsce podczas trwania Powszechnej Wystawy Krajowej. Zob. Zjazd Mistrzów Introligatorskich w Poznaniu, „Polska Gazeta Introligatorska” 1929, nr 7, s. 81-84.

17 Słabość wszystkich gild spowodowała że Związek Cechów nie spełnił oczekiwań i nie podjął żadnej działalności. Zob. I. Kozłowski, Introligatorstwo polskie w dobie obecnej..., s. 152.

18 Zjazd członków izb rzemieślniczych zawodu introligatorskiego w Warszawie, „Polska Gazeta Introligatorska” 1930, nr 7, s. 105-106; (jp), Pierwszy Ogólnopolski Zjazd Introligatorów, „Polska Gazeta Introligatorska" 1930, nr 3, s. 33-42.

19 Sprawozdanie Izby Rzemieślniczej... 1933, s. 28; Sprawozdanie Izby Rzemieślniczej... 1938, s. 108

20 Notki z zebrań Sekcji Introligatorów Zjednoczenia Pracowników Rzemieślniczych: Sprawozdanie z zebrania Sekcji Introligatorów (Oddział Warszawski), „Polska Gazeta Introligatorska” 1930, nr 5, s. 75; Zżycia Sekcji Introligatorów m.st. Warszawy, „Polska Gazeta Introligatorska” 1930, $\mathrm{nr}$ 10, s. 157; Sprawozdanie z rocznego sprawozdawczo-wyborczego zebrania Sekcji Introligatorskiej 
Związku Zawodowego Drukarzy i Pokrewnych Zawodów w Polsce (tzw. II Oddział Warszawa). Sekcja Introligatorów liczyła w 1938 r. ok. 300 członków (54 mężczyzn, 130 kobiet introligatorek i 119 pomocy introligatorskich) ${ }^{21}$. Robotnicy żydowscy byli zgrupowani w pozostającym pod wpływami „Bundu” Związku Zawodowym Robotników Drukarskich w Polsce. Odrębna Sekcja Introligatorów istniała przy Związku Zawodowym Robotników Przemysłu Chemicznego i Pokrewnych w RzeczypospolitejPolskiej22.

Jednym ze znaczących dokonań związków pracowniczych była wspólnie przeprowadzona w $1935 \mathrm{r}$. akcja strajkowa o podwyższenie zarobków. Trwała ona trzy tygodnie, a wzięło w niej udział ponad 1000 osób - 95\% wszystkich pracowników introligatorskich Warszawy. Akcja zakończyła się spektakularnym powodzeniem robotników i podpisaniem umowy zbiorowej ze stroną pracodawców (Stowarzyszeniem Zakładów Graficznych, Cechem Introligatorskim oraz żydowskim Cechem Zrzeszonych Introligatorów ${ }^{23}$.

\section{Nauka zawodu}

Nauka zawodu introligatorskiego wciąż odbywała się w trybie warsztatowego terminowania, choć liczba terminatorów była znacznie niższa niż w końcu XIX w., kiedy to co roku na naukę wstępowało od kilkunastu do kilkudziesięciu chłopców ${ }^{24}$. W latach 30 . w warszawskich warsztatach kształciło się zaledwie kilku chłopców, np. w roku 1933 egzamin czeladniczy zdało pięciu, a w 1938 - dziesięciu uczniów ${ }^{25}$. Liczniejsza była grupa młodzieży kształcąca się w szkołach zawodowych.

Zawodu introligatorskiego uczono w Salezjańskiej Szkole Rzemiosł im. ks. Siemca w Warszawie, np. w roku 1933 na czterech rocznikach kształciło

w Warszawie, „Polska Gazeta Introligatorska” 1932, nr 4, s. 58; Sprawozdanie z dorocznego zebrania Sekcji Introligatorów w Warszawie, „Polska Gazeta Introligatorska” 1933, nr 5, s. 80; Sprawozdanie z ogólnego zebrania Sekcji Introligatorów w Warszawie, „Polska Gazeta Introligatorska” 1933, nr 11, s. 174; Sprawozdanie z III. Kwartalnego zebrania Sekcji Introligatorów w Warszawie połaczonego z tradycyjnym opłatkiem, „Polska Gazeta Introligatorska” 1934, nr 2, s. 30.

2175 lat Okręgu Warszawskiego Związu Zawodowego Pracowników Poligrafii 1892-1967, Warszawa 1967, s. 111-112; Sprawozdanie za okres 1936-38. Zwiqzek Zawodowy Drukarzy i Pokrewnych Zawodów w Polsce, Warszawa 1939, s. 6-7.

22 Cennik i regulamin pracy introligatorów warszawskich. Projekt, [Warszawa 1935], s. 8.

23 Strajk introligatorów, „Wiadomości Graficzne” 1935, nr 12, s. 2; Zwycięstwo introligatorów warszawskich, „Wiadomości Graficzne” 1935, nr 13, s. 4; Umowa zbiorowa w przemyśle i rzemiośle introligatorskim w Warszawie z 13 listopada 1935 roku, [Warszawa 1935].

${ }_{24}$ E. Pokorzyńska, Dzieje cechu introligatorskiego w Warszawie, „Acta Poligraphica” 2019, t. 19 , s. 57.

${ }_{25}$ Sprawozdanie Izby Rzemieślniczej [...] 1933, s. 88; Sprawozdanie Izby Rzemieślniczej [...] 1938, s. 114. 
się 40 uczniów ${ }^{26}$, nie było natomiast tej specjalności w Szkole Przemysłu Graficznego im. Marszałka Józefa Piłsudskiego przy ul. Konwiktorskiej 4, prowadzono ją tylko w szkole wieczorowej, tzw. Dokształcającej Szkole Graficznej ${ }^{27}$. Naukę introligatorstwa dla dziewcząt oferowała I Miejska Szkoła Rękodzielnicza Żeńska przy ulicy Kazimierzowskiej $60^{28}$. Drugą placówką z klasą introligatorską była Państwowa Szkoła Przemysłowa Żeńska przy ul. Górnośląskiej, w której instruktorem introligatorstwa był wykształcony w Paryżu artysta introligator W. Grabowski. W roku 1933 na trzech rocznikach klasy introligatorskiej było 51 uczennic $^{29}$. Na skutek reformy szkolnictwa z 1933 r. wygaszano klasy, z zamiarem utworzenia takiej specjalności w gimnazjach, ale do wybuchu II wojny światowej klasy takie nie powstały ${ }^{30}$. W sprawie tej próbowało interweniować Towarzystwo Bibliofilów Polskich ${ }^{31}$.

Osoby niepełnosprawne (głuche) kształcono w Instytucie Głuchoniemych i Ociemniałych; od chwili uzyskania prawa przeprowadzania egzaminów czeladniczych w 1931 r. do 1938 r. wyzwolono tu 15 czeladników introligatorskich $^{32}$. Warsztaty introligatorskie prowadzone były też przez: Zakład Wychowawczy Braci Albertynów (Grochowska 121), Dom Sierot Zboru Ewangelicko-Augsburskiego (Karolkowa 77/79), Bursę Polskiego Komitetu Pomocy Dzieciom (Sapieżyńska 4) oraz Zakład dla Chłopców Koła Prażan

\footnotetext{
26 Sprawozdanie Izby Rzemieślniczej [...] 1933, s. 37.

27 Kursy doksztatcajace zawodowe dla rzemiosła, „Gazeta Przemysłowo-Rzemieślnicza” 1937, nr 18, s. 7.

28 Pierwsza Miejska Szkoła Rękodzielnicza Żeńska, Warszawa 1929; Sprawozdanie Izby Rzemieślniczej [...] 1933, s. 39.

29 Sprawozdanie Izby Rzemieślniczej [...] 1933, s. 39.

30 Rozporządzenie Ministra Przemysłu i Handlu z dnia 30 sierpnia 1933 r. w porozumieniu z Ministrem Wyznań Religijnych i Oświecenia Publicznego o uzupełnieniu rozporządzenia z dnia 14 grudnia 1927 r. w sprawie ustalenia, w jakiej mierze świadectwa ukończenia szkół technicznych uważać należy za dowód odpowiedniej kwalifikacji do kierowania praktycznem kształceniem terminatorów, Dz. U. 1933, nr 70, poz. 519, [online] http://prawo.sejm.gov.pl/isap.nsf/DocDetails. xsp?id=WDU19330700518 [dostęp 16.12.2019].

31 Archiwum Biblioteki Uniwersytetu Warszawskiego IX/84a, Kopia listu Towarzystwa Bibliofilów Polskich w Warszawie do Ministerstwa Wyznań Religijnych i Oświecenia Publicznego: „Ze względu na to, iż na całym terenie Państwa Polskiego nie ma ani jednej specjalnej szkoły introligatorskiej, a są tylko wydziały introligatorskie w Państwowej Szkole Przemysłowej Żeńskiej w Łodzi i w I Miejskiej Szkole Rękodzielniczej w Warszawie, oraz ze względu na konieczność rozwijania zawodu introligatorskiego w związku z wzrastającym i mającym nadal rosnąć rozwojem czytelnictwa i spożycia książki, utworzenie takiego gimnazjum niezbędne jest dla kultury polskiej gdyż introligatorstwo ma na celu w pierwszym rzędzie konserwację książki i podniesienie jej estetycznego wyglądu. P. Władysław Grabowski, fachowo-wykształcony artysta-introligator, były stypendysta Funduszu Kultury Narodowej I Departamentu Sztuki MWRiOP, własnymi pracami introligatorskimi oraz wynikami swej kilkuletniej pracy pedagogicznej w Państwowej Szkole Przemysłowej Żeńskiej w Warszawie udowodnił, iż zarówno twórczą pracę osobistą, jak i nauczanie introligatorstwa umie postawić na wysokim poziomie, którego brak dotychczas introligatorstwu polskiemu".

32 E.Z., Uroczystość święta szkolnego w Instytucie Gluchoniemych i Ociemniatych w Warszawie, „Dziennik Urzędowy Kuratorium Okręgu Szkolnego Warszawskiego” 1937, nr 2, s. 114-117.
} 
„Sierocin” (Jagiellońska 3/5) ${ }^{33}$. Nauczycieli robót ręcznych kształcono w Państwowym Instytucie Robót Ręcznych im. Władysława Przanowskiego. Nauczyciel tej placówki, Walenty Czyżycki jest autorem wielu artykułów publikowanych w periodyku szkoły - „Prace Ręczne w Szkole”- które złożyły się na wydany już po wojnie podręcznik Introligatorstwo ${ }^{34}$.

\section{Wystawy}

W 1933 r. Izba Rzemieślnicza zorganizowała w sali Rady Miejskiej wystawę prac warsztatowych i szkolnych młodzieży rzemieślniczej oraz zabytków cechowych. Na wystawie zabrakło prac terminatorów introligatorskich, natomiast kilka opraw i albumów pokazali uczniowie Instytutu Głuchoniemych. Do działu historycznego cech introligatorski udostępnił swe najcenniejsze pamiątki: sztandar oraz oryginalny pergaminowy dokument przywileju nadany cechowi przez króla Augusta II w roku $1699^{35}$.

Inne wystawy prezentowały prace rzemiosła artystycznego oraz nowoczesne oprawy wydawnicze. Udział w wystawach przemysłowych był dla rzemieślników głównym sposobem popularyzacji i reklamy, szansą na zdobycie nagród, wykorzystywanych później w działaniach marketingowych. W latach 30. odbyło się kilka takich wystaw.

Duża ekspozycja współczesnej polskiej sztuki introligatorskiej miała miejsce podczas zorganizowanej przez Towarzystwo Bibliofilów Polskich w Warszawie w 1936 r. Wystawie Pięknej Książki Polskiej, towarzyszącej IV Zjazdowi Bibliotekarzy Polskich. Spośród introligatorów warszawskich wystąpili tam ze swoimi pracami J. Recmanik, F.J. Radziszewski, B. Zjawiński, Z. Dębicka i jej niedawna uczennica Helena Karpińska, Introligatornia Artystyczna W. Michalskiej, Henryk Zawistowski, Anna Hoffmanowa i J. Pietrzak. Zaprezentował się W. Grabowski razem ze swymi uczennicami z Państwowej Szkoły Przemysłowej Żeńskiej. Wśród opraw nakładowych znalazły się edycje Jakóba Mortkowicza i „Biblioteki Polskiej”. Ogółem $\mathrm{w}$ dziale introligatorstwa nowoczesnego, jednym z czterech tej wystawy, przedstawiono blisko 400 najlepszych opraw książkowych tej epoki.

\footnotetext{
33 Księga adresowa Polski..., s. 193; Opieka nad macierzyństwem, dziećmi i młodzieża w Rzeczypospolitej Polskiej, Warszawa 1928, s. 58, 60, 63-64, 72.

34 W. Czyżycki, Jak uczyć robót z papieru, kartonu i tektury, „Praca Ręczna w Szkole” 1930, nr 2, s. 18-32, nr 3-4, s. 78-87; 1931, nr 1, s. 20-26, nr 2-3, s. 33-56, nr 4, s. 27-53; 1932, nr 1, s. $25-$ 40, nr 3, s. 211-229; 1933, nr 1-2, s. 82-90, nr 2, s. 123-136; tenże, Zajęcia rękodzielnicze z papieru, kartonu, tektury, Poznań 1934; tenże, Introligatorstwo. Wskazówki techniczne, Warszawa 1948.

35 Wystawa prac warsztatowych i zabytków cechowych, „Gazeta Przemysłowo-Rzemieślnicza” 1933, nr 7, s. 7-8; Zdjęcia z wystawy posłużyły za ilustrację do artykułu Zarys historii cechów (Rzemiosła w Polsce), „Gazeta Przemysłowo-Rzemieślnicza” 1936, nr specjalny wydany łącznie z nr 8, s. 56-64, fotografia fragmentu ekspozycji z przywilejem introligatorskim na s. 57 .
} 
Wszystkie one zostały opisane w obszernym katalogu, a wiele z nich zreprodukowano $^{36}$.

Wielki dział polski na Wystawie Światowej „Sztuka i Technika” w Paryżu w 1937 r. zajmował cały pawilon. Duża i znacząca była ekspozycja sztuki graficznej i książki. Z introligatorstwa warszawskiego zaprezentowano prace W. Grabowskiego oraz jego uczennic z klasy introligatorskiej, oprawy Introligatorni Artystycznej W. Michalskiej, F.J. Radziszewskiego oraz prace zakładu B. Zjawińskiego. Szkoła Przemysłowa oraz Radziszewski i Zjawiński odznaczeni zostali dyplomami honorowymi, natomiast Introligatornia Artystyczna uzyskała najwyższe odznaczenie - Grand Prix, a pięciu jej pracowników otrzymało dyplomy honorowe ${ }^{37}$.

Odbywająca się w Berlinie w 1938 r. Międzynarodowa Wystawa Rzemiosł stała się okazją do kolejnej prezentacji wyrobów rękodzielniczych. Funkcje organizacyjne wzięła na siebie Izba Rzemieślnicza. Z artystycznymi oprawami książek wystąpili J. Recmanik, H. Zawistowski, B. Zjawiński, Introligatornia Artystyczna W. Michalskiej oraz Oficyna Warszawska ${ }^{38}$.

Na Wystawę Światową w Nowym Jorku w 1939 r. wysłane zostały oprawy H. Karpińskiej; ponadto przeszło 120 opraw nakładowych znalazło się w dziale Wydawnictwa ${ }^{39}$.

Introligatorzy biorący udział w wystawach należeli do czołówki warszawskiego introligatorstwa, a w szczególności stanowili grupę fachowców poświęcających się sztuce oprawy. Uzyskiwane przez nich nagrody świadczą o wysokim, porównywalnym z zagranicznym, poziomie realizowanych prac.

\section{Zakłady introligatorskie}

Na czele warszawskiego introligatorstwa stał starszy cechu W. Miernicki. Zakład Miernickiego założony przez jego ojca w 1873 r. mieścił się początkowo przy ul. Elektoralnej, zajmował się głównie produkcją ksiąg handlowych, zatrudniał 50 osób. W przeprowadzce do nowej siedziby na obrzeża miasta (Leszno 92) należy domyślać się znaczącego powiększenia zakładu.

Podstarszym cechu był B. Zjawiński prowadzący zakład przy ul. Nowy Świat 41. Firma powstała w 1912 r., Zjawiński zebrał kapitał na dostawach

\footnotetext{
36 Katalog wystawy pięknej książki polskiej, Warszawa 1936, s. 43-71.

37 Catalogue officiel de la Section Polonaise à l'Exposition Internationale Arts et Techiquesdans la viemoderne, Paris 1937, Warszawa 1937, s. A43-A45 ; Sprawozdanie o pracach jury międzynarodowego, Warszawa 1939, s. 22, 35.

38 Sprawozdanie Izby Rzemieślniczej [...] 1938, s. 63, 66-67; Międzynarodowa Wystawa Rzemiost w Berlinie 28 V-10 VII 1938. Dziat polski, Warszawa 1938, s. 23.

39 Katalog oficjalny dzialu polskiego na międzynarodowej wystawie w Nowym Jorku 1939, Warszawa 1939, s. C235-C236, H412-H418.
} 
dla wojska w okresie I wojny światowej i stworzył znaczący warsztat, specjalizujący się w seryjnych oprawach wydawniczych. Oprawiał nakłady książek wydawnictw Michała Arcta, Głównej Księgarni Wojskowej i innych ${ }^{40}$.

Wśród zakładów rzemiosła artystycznego pierwsze miejsce zajmowała pracownia J. Recmanika (Nowy Świat 55) istniejąca od 1901 r. Specjalizowała się ona w wykonywaniu opraw luksusowych i bibliofilskich, tek i wytwornej galanterii ${ }^{41}$. Zakład H. Zawistowskiego (Krakowskie Przedmieście 40) istniejący od 1889 r., specjalizował się w oprawie grafik, wykonywał też monumentalne oprawy ksiąg i albumów. Zawistowski zmarł w 1936 r., ale warsztat istniał do wojny ${ }^{42}$. Najbardziej znanym warszawskim mistrzem oprawy był F.J. Radziszewski (Mariensztat 23). Od lat 30. pracował wspólnie z synami Stefanem i Janem, tworząc liczne, bogato zdobione oprawy w specyficznym, samodzielnie wypracowanym stylu ${ }^{43}$. Natomiast Z . Dębicka była introligatorką-amatorką, wykonywała oprawy w solidnej, francuskiej technice dla domowej biblioteki oraz niezbyt liczne zlecenia ${ }^{44}$. Renomą cieszył się również warsztat W. Dippla (Nowy Świat 26), który po śmierci mistrza w 1934 r. prowadziła wdowa wraz z synem ${ }^{45}$. Niezwykle wysoki poziom osiągnęła Introligatornia Artystyczna (Wspólna 50) prowadzona przez W. Michalską, wykonująca głównie luksusowe oprawy wydawnictw firmy Trzaska, Evert i Michalski, ale też artystyczne oprawy indywidualne ${ }^{46}$.

W latach 30. do grupy tej dołączyli kolejni artyści, przybywający z innych miast. B. Lenart wcześniej pracował w Krakowie i Wilnie, został sprowadzony do nowo zakładanej w Bibliotece Narodowej pracowni introligatorsko-konserwatorskiej ${ }^{47}$. W. Grabowski objął posadę nauczyciela zawodu w Państwowej Szkole Rękodzielniczej Żeńskiej ${ }^{48}$. Pojawili się też uzdolnieni

\footnotetext{
40 E. Pokorzyńska, Zjawiński Bolesław, [w:] SKPK, s. 320-321.

41 E. Pokorzyńska, Jan Recmanik, 1874-1949. Artysta introligator, Bydgoszcz 2014.

42 J. Kucel, Zawistowscy z Krakowskiego Przedmieścia, „Kurier Warszawski” 2009, nr 4-5, s. $36-37$.

43 J. Długosz, Radziszewski Franciszek Joachim, [w:] SPKP. Suplement, Warszawa 1986, s. 182; M. Hilchen, Pomyślat, rysowat, wykonat Franciszek Joachim Radziszewski, [w:] Oprawy artystyczne Franciszka Joachima Radziszewskiego, Łódź 1987, s. nlb; S. Rowiński, Europejskość i polskość..., dz. cyt.

44 E. Pokorzyńska, Zofia Dębicka - introligatorka z warszawskiej elity, „Roczniki Biblioteczne" 2015, t. 59, s. 73-90.

45 E. Pokorzyńska, Dippel Włodzimierz, [w:] SPKP. Suplement III, s. 62.

46 P. Grajnert, Michalska Wanda, [w:] SPKP. Suplement IV, Warszawa 2016, s. 159-160; Z. Krzyżanowski, Oprawy artystyczne, „Przegląd Literacki” 1930, nr 5-6, s. 115-116.

47 H. Tadeusiewicz, Lenart Bonawentura, [w:] SPKP. Suplement, s. 117-118.

48 S. Mravincsics, Młody artysta introligator Władysław Grabowski, Poznań 1932; Oprawy, „Arkady” 1936, nr 5, s. 282-283; T. Cieślak, H. Wolszczanowa, Grabowski Władysław, [w:] SPKP, Warszawa-Łódź 1972, s. 288.
} 
wychowankowie: Jan Woźniakowski, uczeń F. J. Radziszewskiego ${ }^{49}$, Włodzimierz Wnuk, laureat nagrody Zarządu Miejskiego dla Rzemiosła w 1938 r. $^{50}$ oraz H. Karpińska, która uczyła się introligatorstwa u Z. Dębickiej ${ }^{51}$. W Warszawie więcej kobiet tworzyło piękne oprawy, były to uczennice Grabowskiego z Państwowej Szkoły Rękodzielniczej Żeńskiej ${ }^{52}$, a także zupełne amatorki, jak żona warszawskiego bibliofila Henryka Szeryńskiego ${ }^{53}$.

Wśród tradycyjnych introligatorów-rzemieślników wyróżniał się Z. Szafranek, który w Bibliotece na Koszykowej założył warsztat oprawiający biblioteczne woluminy. Pasjonując się logistyką, Szafranek urządził warsztat w ten sposób, by wysokiej jakości oprawy wykonywać sprawnie i tanio ${ }^{54}$. Zakład W. Drawdzika i A Mościckiego (Chmielna 16) był kontynuacją istniejącego od 1876 r. zakładu Antoniny Szpakowskiej, specjalizował się w oprawach bibliotecznych. M. Wołłowicz i Mieczysław Malus (Widok 12) zajmowali się oprawą wydawniczą i podklejaniem planów. W 1939 r. Wołłowicz otworzył nową dużą introligatornię (Moniuszki 4), która była zakładem pierwszej kategoriii ${ }^{55}$. Inna drogą szedł Jan Dziewulski, dla którego priorytetem była działalność handlowa, tj. trzy sklepy z artykułami papierniczymi mieszczące się przy Krakowskim Przedmieściu i przy ul. Marszałkowskiej; ponadto firma składała się z drukarni, introligatorni i fabryki ksiąg buchalteryjnych (Senatorska 10). Fabryka ksiąg handlowych J. Leśniewskiego (Nowogrodzka 78), niegdyś będąca własnością Wilhelma Kreuscha, miała także duży dział drukarski. Właściciel był członkiem Stowarzyszenia Właścicieli Zakładów Graficznych, był też zapewne członkiem cechu, bowiem brał udział w Ogólnopolskim Zjeździe Przedstawicieli Zawodu Introligatorskiego w Warszawie w 1931 r. Miło zapisał się w pamięci uczestników zjazdu, gdyż:

Wreszcie krótko przed rozejściem się tak niezwykle sympatycznego towarzystwa usłyszeliśmy krótkie przemówienie p. Leśniewskiego, który z właściwym sobie humorem i tupetem zaprosił całe towarzystwo do swych prywatnych apartamentów, gdzie raczył obficie gości wyborowym winem i miodem. Doprawdy nastrój przy winku wytworzył się niesamowity, bo beztroski i wesoły. Uczestnikom zjazdu pozostały mile i niezatarte wspomnienia, a p. Leśniewskiemu próżne butelki od wina ${ }^{56}$.

49 W. Łysiak, Wyspa zaginionych skarbów, Chicago-Warszawa 2001, s. 300.

50 Sprawozdanie Izby Rzemieślniczej [...] 1938, s. 23.

51 E. Pokorzyńska, Karpińska Helena, [w:] SPKP. Suplement III, s. 128-129.

52 Fotografia opraw zob. „Arkady” 1936, nr 6, s. 353.

53 E. Pokorzyńska, ,Proximus”. O szczególnie bliskich kontaktach introligatorów z klientami, [w:] Introligatorzy i ich klienci, red. A. Wagner, Torun 2017, s. 237-242.

54 E. Pokorzyńska, P. Marcinkowski, Zdzisław Szafranek (1906-1972), [w:] Żyja w naszej pamięci. Wspomnienia o pracownikach Biblioteki Publicznej m.st. Warszawy, wyd. 2, red. J. Myszkowska, Warszawa 2017, s. 100-104.

55 M. Wojewódzki, $W$ tajnych drukarniach..., s. 206.

56 (jp), Pierwszy Ogólnopolski Zjazd Introligatorów..., s. 42. 
Wiele większych zakładów prowadziło wytwórczość o charakterze fabrycznym, produkując księgi handlowe, opakowania, albumy, wyroby papiernicze czy galanterię introligatorską. Tą drogą poszedł najznaczniejszy we wcześniejszym okresie zakład Jana Pugeta, który po przedwczesnej śmierci mistrza w 1921 r. prowadził syn Tadeusz: firma specjalizowała się w produkcji opakowań oraz tłoczeniu metalowych szyldów ${ }^{57}$.

Warsztaty introligatorskie działały też w różnych instytucjach państwowych i samorządowych. Należały do nich Bank Polski, Państwowy Bank Rolny (pracownią kierował Zygmunt Komendarczyk) i Więzienie Karne przy ul. Długiej. Powstawały także zakłady introligatorskie o statusie spółdzielni lub warsztatu firmowanego przez jakąś organizację. Do pierwszej grupy należała Robotnicza Spółdzielnia Wytwórcza „Introligator” oraz Towarzystwo Akcyjne Urządzeń Szkolnych i Laboratoryjnych „Urania”, posiadająca wytwórnię zeszytów i ksiąg handlowych, drukarnię, introligatornię, stolarnię oraz skład handlowy materiałów piśmiennych i pomocy szkolnych ${ }^{58}$. W grupie drugiej znajdują się warsztaty introligatorskie prowadzone przez Związek Inwalidów Wojennych Rzeczypospolitej Polskiej czy Związek Zawodowy Pracowników Samorządu Terytorialnego Rzeczypospolitej Polskiej.

W okresie międzywojennym szereg drukarń, posiadając dział introligatorski, oferowało pełen kompleks usług poligraficzno-introligatorskich. Niektóre $\mathrm{z}$ nich były uwzględniane $\mathrm{w}$ księgach adresowych $\mathrm{w}$ dziale zakładów introligatorskich, jak np.: M. Arct (Czerniakowska 224), Tadeusz Bogusławski (Trębacka 15), Bolesław Bukaty (Hoża 51), Kazimierz i Eugeniusz Koziańscy (Krakowskie Przedmieście 66), Bolesław Wierzbicki (Chmielna 61), J. Leśniewski (Nowogrodzka 78) ${ }^{59}$. Fotografie przedstawiające dział introligatorski w drukarni M. Arcta zawarł Michał Arct jr. w książeczce Jak powstaje ksiaż$k a^{60}$.W tych introligatorniach realizowano broszurowanie książek, a niektóre zakłady wykonywały także oprawy twarde, jak np. drukarnia Straszewiczów ${ }^{61}$.

\section{Wyposażenie warsztatów}

Coraz częściej realizowana oprawa nakładowa książek, obejmująca w latach $30 . \mathrm{XX}$ wieku $10 \%$ całej produkcji poligraficznej ${ }^{62}$, pociągała za sobą

57 [Reklama. J. Puget i S-wie], „Gazeta Przemysłowo-Rzemieślnicza” 1936, nr specjalny wydany łącznie z $\mathrm{nr} 8$, s. [76].

58 Nasz Sklep - Urania sp. akc. X sprawozdanie rachunkowe 1 I 1921 - 30 VI 1922, Warszawa 1922; Nasz Sklep - Urania sp. akc. Kalendarz 1927, Warszawa 1927; „Kalendarz Na Pogotowie Ratunkowe" 1937, s. 461.

59 Księga adresowa Polski..., 1938, s. 191-193.

60 M. Arct, Jak powstaje książa, Warszawa 1929, s. 51, 53.

${ }_{61}$ N. Waln, Dom na wygnaniu, Warszawa 1936: informacja w stopce redakcyjnej.

62 I. Kozłowski, Introligatorstwo polskie w dobie obecnej..., s. 152. 
rozbudowę i uprzemysłowienie niektórych zakładów introligatorskich. W 1932 r. 27 warszawskich introligatorni zaliczono do przemysłu poligraficznego, zatrudniały one łącznie 234 robotników (w tym 116 mężczyzn, 90 kobiet, 13 chłopców i 15 dziewcząt) ${ }^{63}$. Podstawowe maszyny, czyli gilotynę i prasę do złocenia posiadały prawie wszystkie warsztaty introligatorskie. Na wyposażenie techniczne większych zakładów składało się wiele maszyn, np. zakład Zjawińskiego był wyposażony w dwie maszyny do szycia książek drutem, dwie niciarki i dwie zszywarki blokowe (tzw. łabędziówki), trzy gilotyny (najpierw ręczne, potem z napędem elektrycznym), trzy prasy do złocenia ${ }^{64}$, Introligatornia Artystyczna W. Michalskiej miała zaś maszynę do szycia książek nićmi, gilotynę do obcinania brzegów, dwie prasy do złocenia, obijaczkę do zaokrąglania grzbietów ${ }^{65}$. Introligatorzy polscy korzystali głównie z maszyn niemieckiej produkcji. W roku 1925 informowano, że dotychczas sprowadzono do polskich zakładów 2600 maszyn z fabryki Krausego (gilotyny, prasy do złocenia) oraz 1250 maszyn Brehmera (zszywarki i falcerki) ${ }^{66}$. Zaopatrzenie w materiały zapewniało szereg sklepów z firmą Jana Siudeckiego na czele ${ }^{67}$.

\section{Oprawy książek}

Zdecydowana większość opraw książek jest anonimowa, nieznany pozostaje zarówno projektant warstwy dekoracyjnej jak i wykonawca - introligator. Funkcja wykonawcy i artystycznego kreatora zaczyna rozdzielać się w wieku XIX, choć miało miejsce wiele modeli postępowania. Według tradycyjnego to sam introligator tworzył i realizował wystrój oprawy, dysponując własnymi umiejętnościami, obowiązującymi schematami i modą, wyposażeniem narzędziowym swego warsztatu, biorąc pod uwagę życzenia klienta. Uwzględniając wieloosobowy skład pracowniczy warsztatów, trzeba pamiętać, że artystycznym liderem nie musiał być właściciel warsztatu, lecz któryś z zatrudnionych u niego pracowników-czeladników ${ }^{68}$. Wraz z rozwojem oprawy wydawniczej, coraz częściej pojawia się projektant (zawodowy artysta, zwykle malarz grafik lub architekt), zewnętrzny wykonawca pracujący nie tyle na zlecenie introligatora, co wydawcy. Udział artystów większy był w projektowaniu okładek

63 Rocznik statystyczny Warszawy 1932, Warszawa 1934, s. 54.

64 Notka z rozmowy z Zygmuntem Zjawińskim przeprowadzonej 5 XII 1995.

${ }_{65}$ K. Zbyszewski, Kuźnia ksiażki, „Przegląd Literacki” 1930, nr 5-6, s. 4-5.

66 [Reklama], „Przemysł Graficzny” 1925, nr 11-12, okładka s. 3.

67 (jp), Z otwarcia „Centrali” J.K. Siudecki w Warszawie, „Polska Gazeta Introligatorska” 1930, nr 2, s. 24-27.

68 Krakowski introligator Robert Jahoda zatrudniał w swym zakładzie uzdolnionego młodego artystę Franciszka Seiferta, fakt projektowania przez niego opraw w nowoczesnym, zgeometryzowanym stylu został przedstawiony w artykule (W.K.), Oprawy introligatorskie pomyslu Franciszka Seiferta, „Rzeczy Piękne” 1927, nr 1, s. 6-7. 
papierowych, zdobionych techniką typograficzną lub litograficzną, okładki płócienne lub skórzane częściej dekorowano kompozycjami tłoków i plakiet, posiadanych $\mathrm{w}$ warsztatowym zasobie. Proces świadomego, artystycznego tworzenia projektu okładki rozwija się na przełomie XIX/XX w., u schyłku okresu międzywojennego zatrudnianie profesjonalistów do stworzenia projektu okładki było już bardzo częste, a sygnatura autorska pojawia się na drukarskich okładkach. Natomiast sygnowanie opraw twardych, tak indywidualnych jak wydawniczych, zarówno przez introligatora jak i projektanta należy do wyjątków.

Niektóre książki posiadają sygnaturę introligatorską lub notkę w stopce wydawniczej, lecz są to przypadki sporadyczne. Zachowały się ogólnikowe informacje o kooperacji poszczególnych wydawców i introligatorów, lecz nie wiadomo, czy były to umowy stałe czy jednostkowe porozumienia dotyczące wybranych edycji i rzadko można powiązać je z konkretnym artefaktem.

I tak na przykład firma M. Arcta w swej zakładowej introligatorni realizowała tylko broszurowanie książek i czasopism, natomiast trudniejsze technologicznie oprawy twarde zlecała introligatorni B. Zjawińskiego ${ }^{69}$. Tamże oprawiane były książki wydawane przez Główną Księgarnię Wojskową. Przedsiębiorstwo Gebethnera i Wolffa współpracowało z warsztatem W. Dippla, a introligatornia Zygmunta Markiewicza oprawiała podręczniki Komitetu Wydawniczego Podręczników Akademickich w jednolitej szacie wydawniczej z sygnetem Kasy im. Mianowskiego ${ }^{70}$.

J. Mortkowicz, właściciel Towarzystwa Wydawniczego w Warszawie, początkowo korzystał z usług chałupników żydowskich, w 1926 r. założył własną drukarnię i introligatornię na Rynku Starego Miasta 11, którą tak opisywała córka wydawcy, Hanna Mortkowicz-Olczakowa:

Ale przyznam się, że kiedy chcę wspominać naszą pracę codzienną, nasze nakładowe, tak powszechnie znane oprawy, okładki „Pod Znakiem Poetów” różnobarwne jak kwiaty, granatowe tomy Żeromskiego ze złotą dębową gałązką, płócienne tomy powieści Struga, dzieł Zielińskiego, poezji Staffa, to staje mi przed oczyma niepozorna, bynajmniej nie reprezentacyjna postać Goldfedera. Nie pamiętam już jego imienia. Nie mogę sobie uprzytomnić, czy chodził jeszcze w rytualnym chałacie, czy ubierał się już - jak się to wtedy nazywało - ,półdługo”, czy miał na głowie czapkę, czy już kapelusz. [...] Do księgarni towarzyszyły mu zazwyczaj córki, rosłe i przystojne dziewczęta, także introligatorki, które mu pomagały w robocie, a nawet pchały razem z nim wózek naładowany gotowym towarem. [...] Czasami narzekaliśmy na Goldfedera, że coś tam spartaczył, że w pośpiechu nie dopilnował roboty.

69 Muzeum Drukarstwa 171/AA, List Zbysława Arcta do Muzeum Drukarstwa 1987. Świadczy o tym także relacja Z. Zjawińskiego (syna Bolesława), który przekazał do zbiorów Muzeum Drukarstwa Warszawskiego wiele klisz introligatorskich pozostałych po zakładzie ojca, a służących do wytłaczania napisów i sygnetów na wydawnictwach Arctów.

70 Informacje pochodzą z sygnowanych opraw. 
A jednak spod jego rąk książki wychodziły czyste, kwitnące barwami i złoceniami liter. A jednak można mu było zawierzyć bez wahania i żadnej kontroli najkosztowniejsze skóry zakupione w Londynie czy w Paryżu, białe kruki edytorskie.

[...] Kiedy po roku 1926 mój ojciec postanowił uruchomić i unowocześnić drukarnię, pomyślał także o własnej introligatorni. Żeromski w prenumeracie, zarówno broszurowany, jak oprawny w granatowe płótno, szedł wtedy w ogromnych jak na owe czasy nakładach; planowane były dalsze wydania zbiorowe Struga i Staffa. W jednopiętrowej oficynce w tyle podwórza urządził więc ojciec nowoczesną introligatornię.

Na parterze pracowała sprowadzona z Niemiec falcówka Bremmera, na górze zainstalowano nowe maszyny do szycia nićmi i drutem, do sztancowania, nowoczesną gilotynę do cięcia papieru. Do obsługi tych maszyn stanął zespół pracowników zatrudnionych na stały przez wydawnictwo. Na ich czele - właśnie Grzybek, rudy, chudy, ruchliwy, kanciasty, miotał się przy robocie jak w ataku pląsawicy. W tym, małym warsztacie broszurowano i oprawiano w karton albo w płótno wszystkie książki drukowane na Starym Mieście, zszywano je i klejono ${ }^{71}$.

Księgarnia Wydawnicza Trzaski, Everta i Michalskiego posiadała własny zakład pod nazwą Introligatornia Artystyczna. Głównym profilem działalności firmy było broszurowanie publikacji Księgarni Wydawniczej oraz wykonywanie okładek do tychże publikacji, które rozsyłano prenumeratorom. Część niesprzedanego w drodze prenumeraty nakładu oprawiano i kierowano do sprzedaży.

Z kolei Marian Kister, współwłaściciel Towarzystwa Wydawniczego „Rój” korzystał z usług wielu introligatorów żydowskich, często chałupników. Jego córka wspomina, że

otoczony przez drukarzy, dostawców papieru, introligatorów, pisarzy - załatwiał kilkanaście spraw naraz. [...] Dzięki takiemu stylowi pracy zdarzało się, że biedny introligator z Twardej czy Muranowskiej mógł na własne oczy zobaczyć wybitnego pisarza, znanego mu dotychczas tylko z okładki i arkuszy oprawianej przez niego książki ${ }^{72}$.

Równie trudne jest ustalanie projektantów poszczególnych okładek. Z omawianego okresu można wskazać jedynie na Atelier Girs-Barcz jako twórcę projektów (w tym projektów okładek) publikacji Głównej Księgarni Wojskowej i M. Arcta oprawianych przez B. Zjawińskiego. Niektóre oprawy wydawnictwa Trzaski, Everta i Michalskiego projektował Józef Mieszkowski ${ }^{73}$. F.J. Radziszewski był autorem projektu oprawy, a może i wykonawcą kilku książek (Polska, jej dzieje i kultura, 1928-1932; Polska w krajobrazie i zabytkach, 1930; Stanisław Przybyszewski, Listy, 1937). Stanisław Ostoja-Chrostowski zaprojektował okładkę Historii sztuki Ryszarda Hamanna (1934), Feliks Szczęsny

\footnotetext{
71 H. Mortkowicz-Olczakowa, Pod znakiem kłoska, Warszawa 1962, s. 134-136.

72 H. Kister, ,Pegazy na Kredytowej”. Wspomnienia, Warszawa 1980, s. 24, 61.

73 Artystyczne oprawy, [reklama], „Przegląd Literacki” 1931, nr 11-12, s. 5.
} 
Kwarta był projektantem oprawy Konstytucji 1935 oraz Dziejów sztuki polskiej Michała Walickiego i Juliusza Starzyńskiego (1936), zaś B. Lenart autorem okładki encyklopedii Świat i życie (z tym, że ta ostatnia jest dziełem Książnicy-Atlas i być może nie powstała w Warszawie).

Przegląd warszawskich opraw z lat 30. XX w. - zarówno prac indywidualnych jak i wydawniczych - pokazuje, że książka polska przebyła już proces przemiany i modernizacji. Nie spotykamy już niemodnego wzornictwa secesyjnego czy historyzującego. Okładki zostały pozbawione bogatej ornamentacji i ilustracyjności, dominują układy liternicze, geometryczne dekoracje liniowe, oszczędne, niewielkie wymiarowo motywy zdobnicze, symbole i uproszczone rysunki, mające ścisły związek z treścią książek. Znaczna część powierzchni okładki pozostaje wolna od dekoracji, okładki pozbawiono nawet najbardziej tradycyjnego, odwiecznego elementu - ramki. Pojawiają się nowatorskie rozwiązania graficzne, które niewątpliwie wyszły spod ręki profesjonalnych plastyków. Uwagę zwraca liternictwo: nowoczesne, linearne kroje groteskowe, a nawet pismo o eksperymentalnych formach. Chętnie wykorzystywano facsimile podpisu autora oraz sygnety wydawnicze. Napisy na okładkach były przeważnie tłoczone nie przy użyciu składów czcionkowych lecz z klisz drukarskich (podobnie jak elementy graficzne), na co pozwalała rozwijająca się chemigrafia. Oszczędne dekoracje nadały książkom wygląd poważny i elegancki. Oprawy zaczęły uzyskiwać książki użytkowe, poradniki, literatura fachowa, w ich przypadku dominuje funkcjonalizm w postaci standardowych napisów. Bogatsze zdobnictwo pojawia się już tylko na grzbietach. Niektórzy wydawcy (np. J. Mortkowicz, Trzaska, Evert i Michalski, Towarzystwo Wydawnicze „Rój”, Wydawnictwo Gutenberga, „Biblioteka Arcydzieł Literatury") stworzyli swój własny powtarzalny styl zdobienia opraw lub tworzyli długie serie, dzięki czemu ich edycje są dobrze rozpoznawalne.

Oczywiście w całej masie opraw tej epoki pojawiają się oprawy słabsze, konwencjonalne, schematyczne, przestarzałe. Na drugim biegunie znajdą się oprawy luksusowe, bogato zdobione, wykonywane na zlecenie władz, przeznaczane na upominki dla osobistości ${ }^{74}$, realizowane dla bogatych klientów z warstwy ziemiańskiej, sfer wojskowych czy dla bibliofilów. Na te potrzeby najlepiej odpowiadał warsztat Franciszka Joachima i Stefana Radziszewskich, tworzący bogato dekorowane oprawy autorskie.

Introligatorstwo polskie w przededniu II wojny światowej borykało się z wieloma problemami: bezrobociem, skutkami kryzysu światowego, niską przeciętną zamożnością społeczeństwa, skutkującą wąskim gronem klientów. $\mathrm{Z}$ drugiej strony było liczne, nieźle wyposażone, nadążało za prądami artystycznymi i wykonywało prace dobre jakościowo.

74 J. Kot, Dyplomy lubelskie marszałka Rydza-Śmigłego, „Silva Rerum” 1938-1939, t. 7, s. 241. 
Niemiecka agresja i okupacja spowodowały zniszczenie wielu zakładów, zarówno wskutek bombardowań podczas wojny obronnej 1939 r., holocaustu i unicestwienia zakładów żydowskich, jak i codziennej, oszukańczej polityki ekonomicznej. Dzieła zniszczenia dokonały walki uliczne podczas powstania warszawskiego oraz planowe niszczenie miasta po jego upadku.

Utrata materiałów źródłowych nie pozwala na bardziej szczegółowe analizy życia i działalności introligatorów warszawskich, natomiast zachowane egzemplarze książek stanowią wciąż jeszcze otwarte pole badań. Hamuje je trudny dostęp do informacji o interesujących egzemplarzach, spoczywających w bibliotecznych magazynach. Dopiero ujawnienie zasobów, najlepiej w formie bazy opraw umożliwi dalsze, szersze badania. W artykule zasygnalizowane zostało zagadnienie oprawy wydawniczej, które także warte jest dokumentacji i głębszej analizy, nie ograniczonej terytorialnie i chronologicznie jak w niniejszym tekście, tym bardziej że oprawy wydawnicze, jako wieloegzemplarzowe, są znacznie łatwiejsze do uchwycenia. W końcu należy zwrócić uwagę na postać B. Lenarta, osoby niezwykle zasłużonej dla polskiego introligatorstwa oraz konserwacji książki. Poświęcono mu wiele wspomnień i przyczynków, jednak jego działalność zasługuje na wyczerpujące studium.

Fot. 1. Oprawa artystyczna B. Lenarta. S. Żeromski, La Vistule, przeł. S. DuninKarwicki, Varsowie-Cracovie 1924. Własność prywatna. Zdjęcie: E. Pokorzyńska

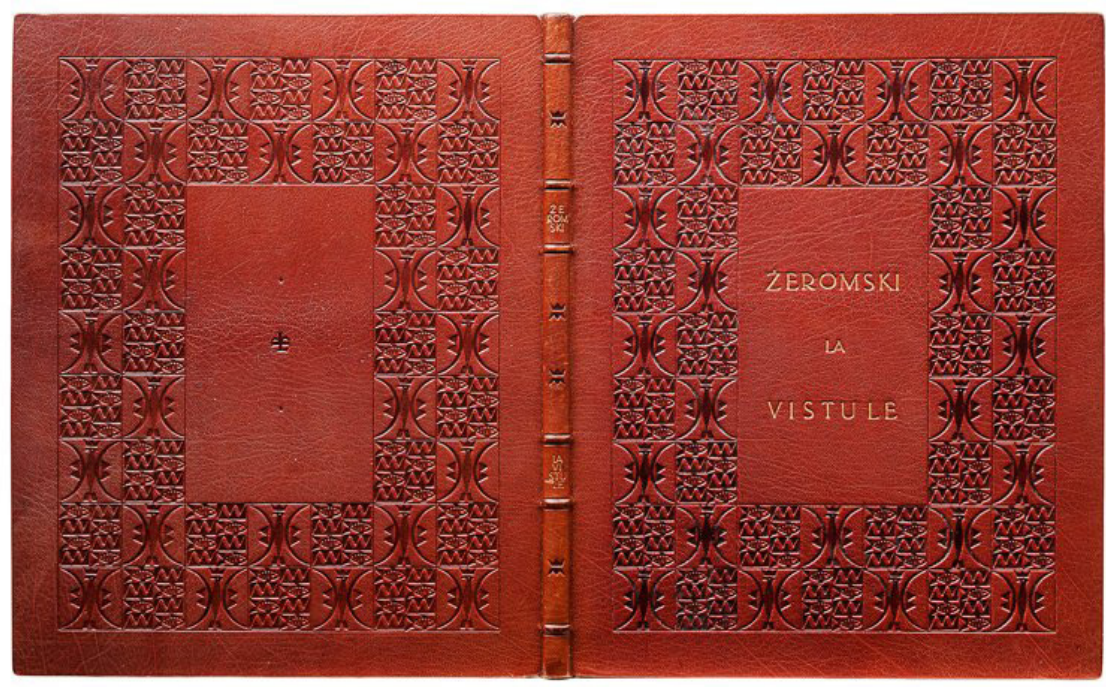


Fot. 2. Oprawa artystyczna F.J.Radziszewskiego. Księga psalmów, przeł. L. Staff, Warszawa 1937. Własność prywatna. Zdjęcie: E. Pokorzyńska

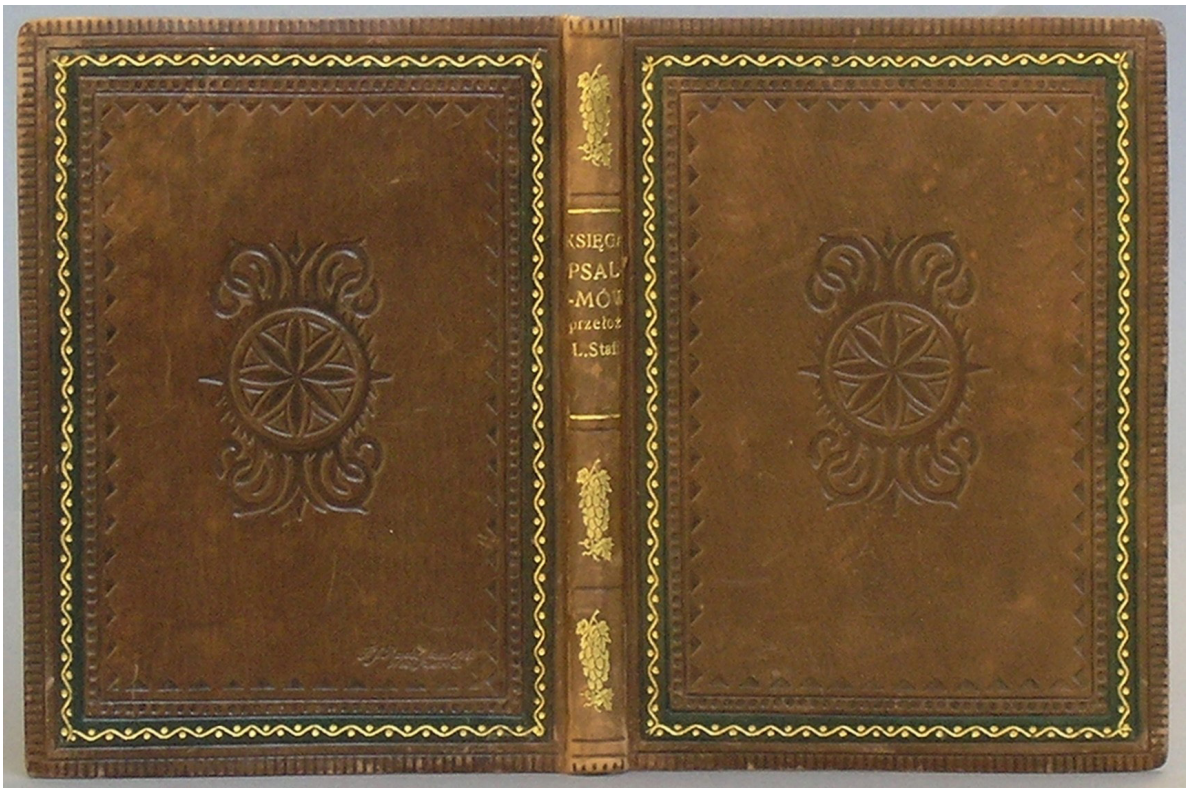

Fot. 3. Oprawa artystyczna H. Zawistowskiego. Adresy hołdownicze dla J. Pitsudskiego od powiatu zabłudowskiego, 1930. Własność Archiwum Akt Nowych

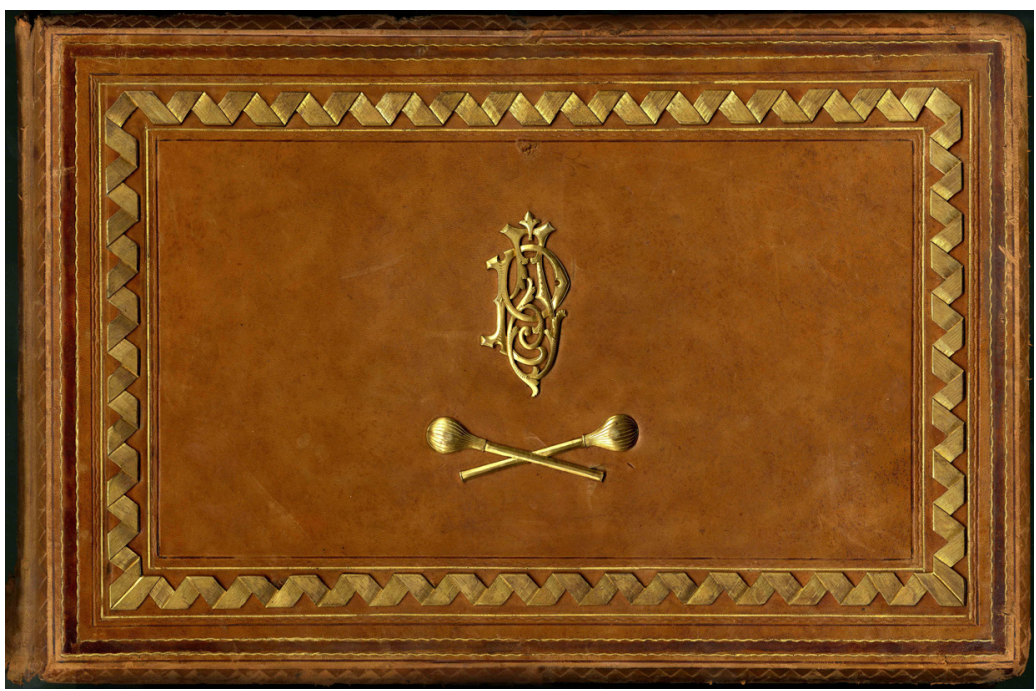


Fot. 4. Oprawa wydawnicza Introligatorni Artystycznej Wandy Michalskiej.

F. Kopera, Dzieje malarstwa w Polsce. T. 1-2, Warszawa: Trzaska, Evert i Michalski, 1925-1929. Zdjęcie: E. Pokorzyńska

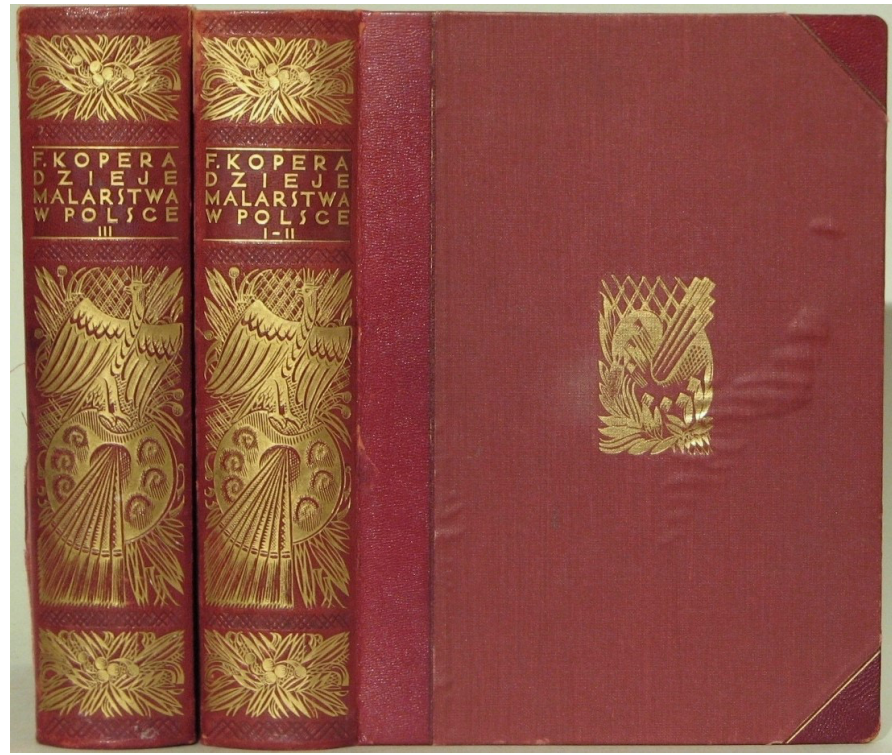

Fot. 5. Oprawa wydawnicza B. Zjawińskiego. E. Maliszewski, B. Olszewicz, Podręczny słownik Geograficzny. T. 1-2, Warszawa: Trzaska, Evert i Michalski, 1925. Zdjęcie: E. Pokorzyńska

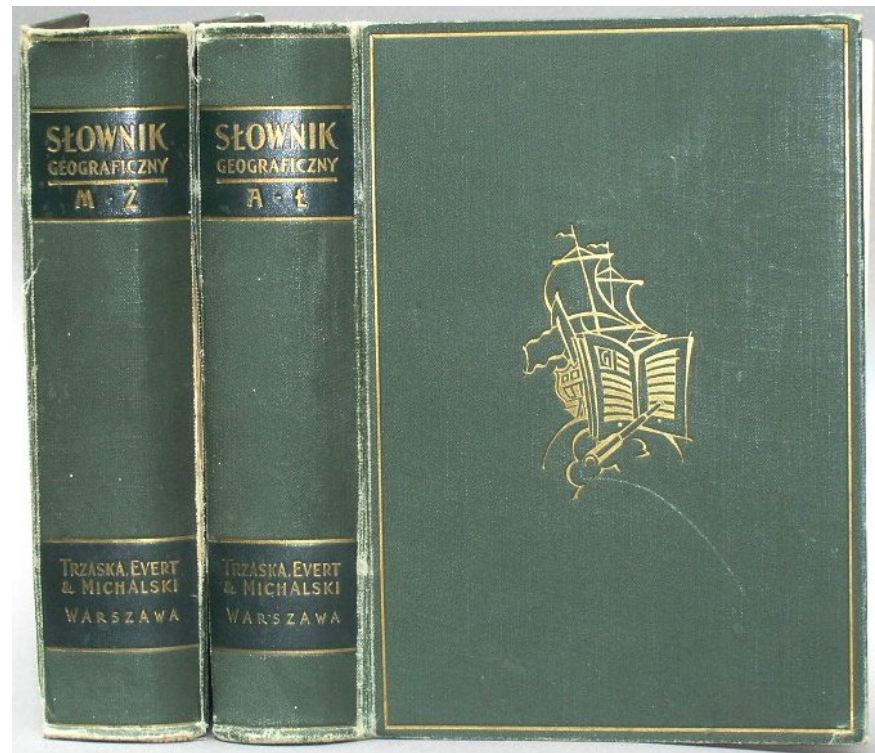


Fot. 6. Oprawa wydawnicza B. Zjawińskiego wg projektu S. Kwarty M. Walicki, Dzieje sztuki polskiej, Warszawa: M. Arct, 1936. Zdjęcie: E. Pokorzyńska

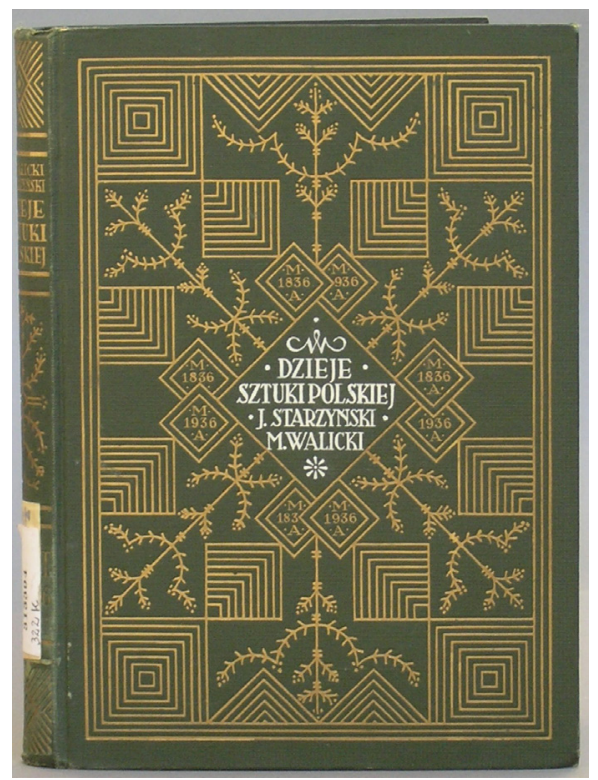

Fot. 7. Oprawa wydawnicza, introligatornia nieznana. M. Arcta słownik ortograficzny języka polskiego, wyd. 6, Warszawa: M. Arct, 1936. Zdjęcie: E. Pokorzyńska

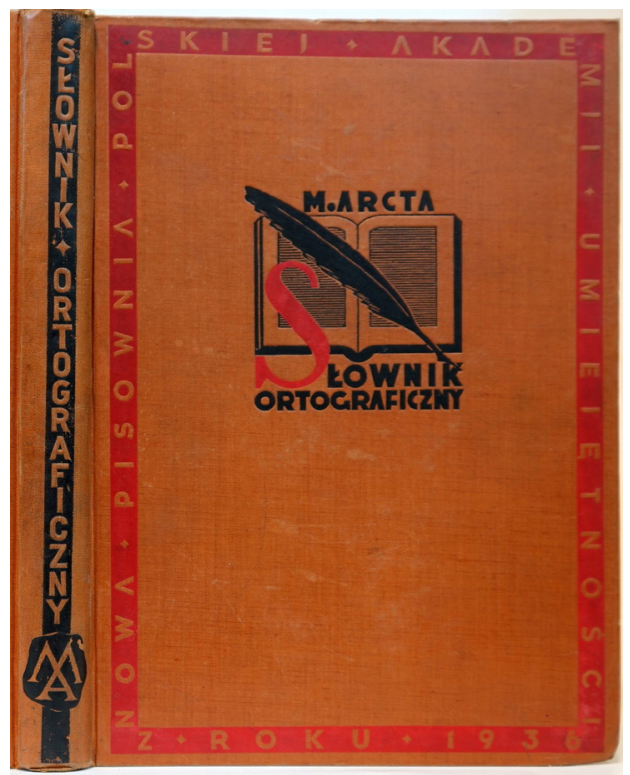


Fot. 8. Oprawa wydawnicza, introligatornia nieznana. B. Kretowicz, O czem szumi Dewajtis, Warszawa: „Rój”, 1929. Zdjęcie: E. Pokorzyńska

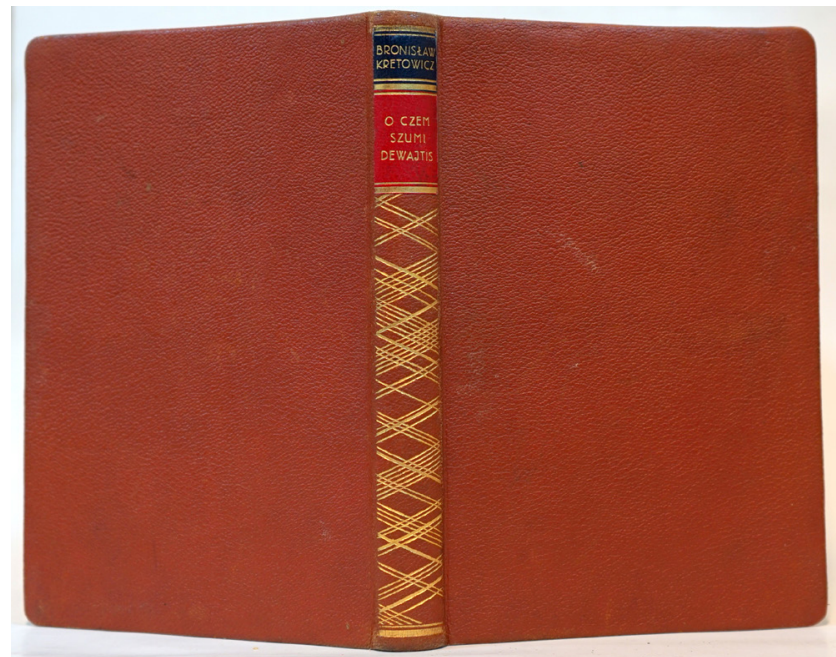

Fot. 9. Oprawa wydawnicza, introligatornia nieznana. Z. Burzyński, „, Kościuszko” nad Ameryka, Warszawa: Wydawnictwo Aeroklubu RP, 1934.

Zdjęcie: E. Pokorzyńska

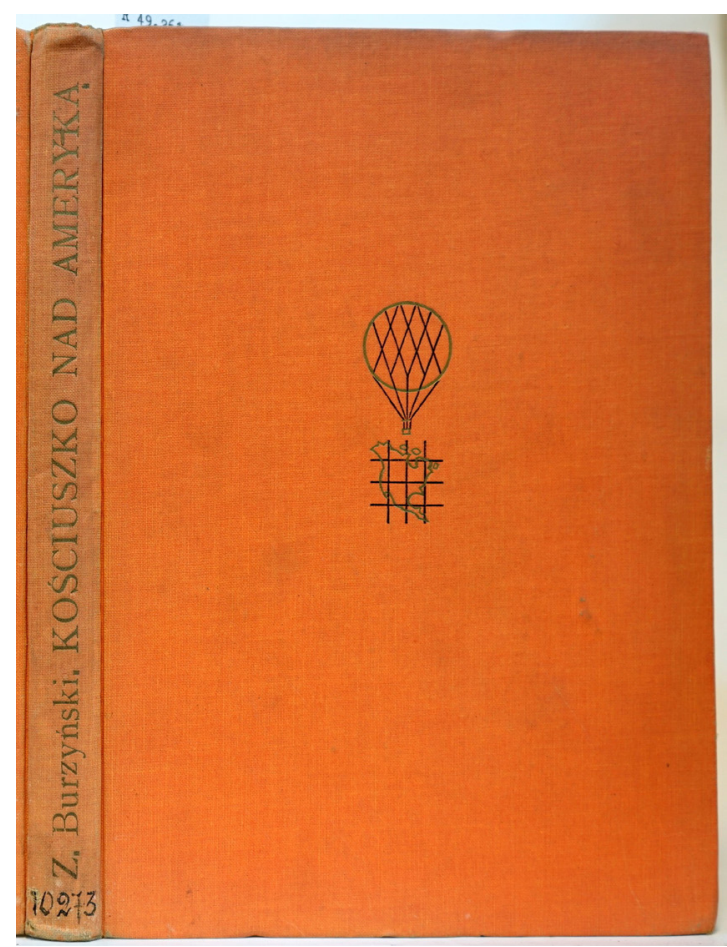


Fot. 10. Oprawa wydawnicza, introligatornia nieznana. H. Bagiński, U podstaw organizacji Wojska Polskiego 1908-1914, Warszawa: Sekcja Historyczna Stow. Uczestników Ruchu Niepodległościowego „Zarzewie”, 1935.

Zdjęcie: E. Pokorzyńska

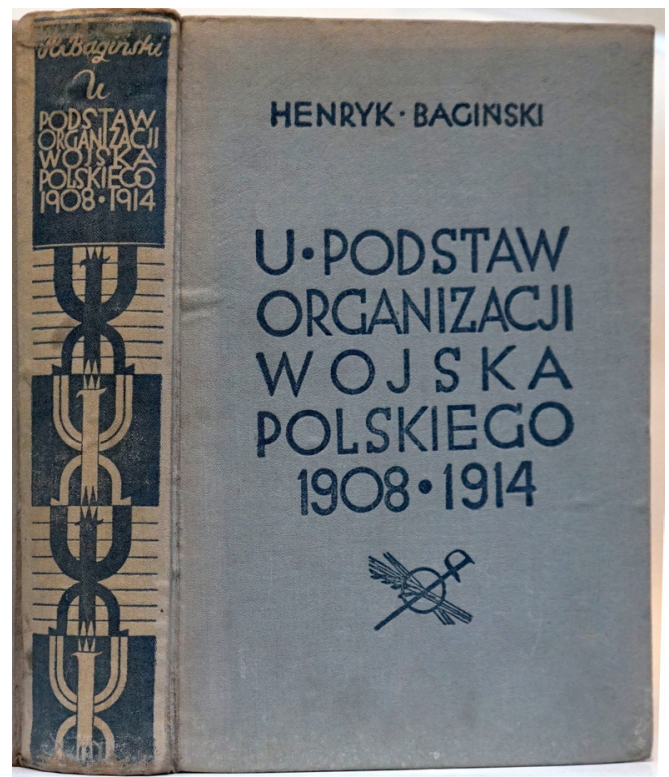

Bibliografia

Źródła archiwalne

Archiwum Biblioteki Publicznej m. st. Warszawy 341/3, k. 84, Odpis świadectwa przemysłowego Introligatorni Artystycznej.

Archiwum Biblioteki Uniwersytetu Warszawskiego IX/84a, Kopia listu Towarzystwa Bi-

bliofilów Polskich w Warszawie do Ministerstwa Wyznań Religijnych i Oświecenia

Publicznego.

Muzeum Drukarstwa 171/AA, List Zbysława Arcta do Muzeum Drukarstwa 1987.

Warszawski Cech Introligatorów, 1950 rps., Akt erekcyjny.

Źródła drukowane

Cennik i regulamin pracy introligatorów warszawskich. Projekt, [Warszawa 1935].

Nasz Sklep - Urania sp. akc. X sprawozdanie rachunkowe 1 I 1921 - 30 VI 1922, Warszawa 1922.

Pierwsza Miejska Szkoła Rękodzielnicza Żeńska, Warszawa 1929.

Sprawozdanie Izby Rzemieślniczej w Warszawie za 1932 r., Warszawa 1933.

Sprawozdanie Izby Rzemieślniczej w Warszawie za 1933 r., Warszawa 1934. 
Sprawozdanie Izby Rzemieślniczej w Warszawie za 1938 r., Warszawa 1939.

Sprawozdanie o pracach jury międzynarodowego, Warszawa 1939.

Sprawozdanie za okres 1936-38. Zwiazek Zawodowy Drukarzy i Pokrewnych Zawodów w Polsce, Warszawa 1939.

Umowa zbiorowa $w$ przemyśle i rzemiośle introligatorskim $w$ Warszawie z 13 listopada 1935 roku, [Warszawa 1935].

Akty prawne

Rozporządzenie Ministra Przemysłu i Handlu z dnia 30 sierpnia 1933 r. w porozumieniu z Ministrem Wyznań Religijnych i Oświecenia Publicznego o uzupełnieniu rozporządzenia z dnia 14 grudnia 1927 r. w sprawie ustalenia, w jakiej mierze świadectwa ukończenia szkół technicznych uważać należy za dowód odpowiedniej kwalifikacji do kierowania praktycznem kształceniem terminatorów, Dz. U. 1933, nr 70, poz. 519.

Rozporządzenie Prezydenta Rzeczypospolitej z dnia 7 czerwca 1927 r. o prawie przemysłowym, Dz. U. 1927, nr 53, s. 697-720, [online] http://prawo.sejm.gov.pl/isap.nsf/ download.xsp/WDU19270530468/O/D19270468.pdf [dostęp 16.12.2018].

Ustawa z dnia 15 lipca 1925 r. o państwowym podatku przemysłowym, Dz. U. 1925, $\mathrm{nr} 79$, poz. 550, [online] http://prawo.sejm.gov.pl/isap.nsf/download.xsp/ WDU19250790550/O/D19250550.pdf [dostęp 16.12.2018].

Ustawa zgromadzeń rzemieślniczych, „Gazeta Przemysłowo-Rzemieślnicza” 1905, nr 16, s. 126.

Kalendarze i księgi adresowe

Chrześcijańska Warszawa. T. 1: Księga informacyjna polskiego przemystu, finansów, handlu, rzemiosła, szkolnictwa, prasy, wolnych zawodów, instytucyj państwowych, samorzadowych i prywatnych, organizacyj gospod., spot., kultur., oświat., naukowych, dobroczynnych., zawodowych, i t.p. miasta stotecznego Warszawy, pod red. S. Kwiatkowskiego, Warszawa 1939.

„Kalendarz na Pogotowie Ratunkowe” 1937.

„Kalendarz Skarbowy na 1936 rok” 1935.

Katalog wystawy pięknej ksiązki polskiej, Warszawa 1936.

Ksiega adresowa Polski. Przemystu, handlu, finansów, szkolnictwa, wolnych zawodów i organizacji spolecznych, wyd. 5, Warszawa 1938.

Księga adresowa przemystu, handlu i finansów, oprac. A.R. Sroka, Warszawa 1926.

Nasz Sklep - Urania sp. akc. Kalendarz 1927, Warszawa 1927.

Rocznik statystyczny Warszawy 1932, Warszawa 1934.

Spis abonentów sieci Telefonicznej m.st. Warszawy P.A.S.T. i Warszawskiej Sieci Okręg P.P.T.T. Rok 1939/1940, Warszawa 1939-1940.

Warszawski skorowidz branżowy na rok 1936-1937. Obejmuje: finanse, przemyst, handel, rzemiosto, wolne zawody, [zest. i oprac. J. Schranz], Warszawa [ok. 1937]. 
Katalogi

Catalogue officiel de la Section Polonaise à l'Exposition Internationale Arts et Techiques dans la vie moderne, Paris 1937, Warszawa 1937.

Katalog oficjalny działu polskiego na międzynarodowej wystawie w Nowym Jorku 1939, Warszawa 1939.

Międzynarodowa Wystawa Rzemiost w Berlinie 28 V-10 VII 1938. Dziat polski, Warszawa 1938 .

Wspomnienia

Kister H., ,,Pegazy na Kredytowej”. Wspomnienia, Warszawa 1980.

Kucel J., Zawistowscy z Krakowskiego Przedmieścia, „Kurier Warszawski” 2009, nr 4-5, s. 36-37.

Mortkowicz-Olczakowa H., Pod znakiem kłoska, Warszawa 1962.

Wojewódzki M., W tajnych drukarniach Warszawy 1939-1944. Wspomnienia, Warszawa 1976.

Inne publikacje

75 lat Okręgu Warszawskiego Związku Zawodowego Pracowników Poligrafii 1892-1967, Warszawa 1967.

Czyżycki W., Jak uczyć robót z papieru, kartonu i tektury, „Praca Ręczna w Szkole” 1930, nr 2, s. 18-32, nr 3-4, s. 78-87; 1931, nr 1, s. 20-26, nr 2-3, s. 33-56, nr 4, s. 27-53; 1932, nr 1, s. 25-40, nr 3, s. 211-229; 1933, nr 1-2, s. 82-90, nr 2, s. 123-136.

Czyżycki W., Zajęcia rękodzielnicze z papieru, kartonu, tektury, Poznań 1934.

E.Z., Uroczystość święta szkolnego w Instytucie Gtuchoniemych i Ociemniatych $w$ Warszawie, „Dziennik Urzędowy Kuratorium Okręgu Szkolnego Warszawskiego” 1937, nr 2, s. 114-117.

(jp), Pierwszy Ogólnopolski Zjazd Introligatorów, „Polska Gazeta Introligatorska” 1931, nr 3, s. 33-42.

(jp), Z otwarcia „Centrali” J.K. Siudecki w Warszawie, „Polska Gazeta Introligatorska” 1930, nr 2, s. 24-27.

Kot J., Dyplomy lubelskie marszałka Rydza-Śmigłego, „Silva Rerum” 1938-1939, t. 7, s. 241.

Kozłowski I., Introligatorstwo polskie w dobie obecnej, „Przegląd Graficzny, Wydawniczy i Papierniczy" 1939, nr 15-16, s. 151-153.

Krzyżanowski Z., Oprawy artystyczne, „Przegląd Literacki” 1930, nr 5-6, s. 115-116.

Kto może otworzyć warsztat rzemieślniczy, „Polska Gazeta Introligatorska” 1930, nr 2, s. $15-16$, nr 3, s. 44-46.

Kursy doksztatcajace zawodowe dla rzemiosła, „Gazeta Przemysłowo-Rzemieślnicza” 1937, nr 18, s. 7.

M.M., Introligatorstwo w świetle polskiej ustawy przemysłowej, „Polska Gazeta Introligatorska” 1929, nr 11, s. 143-144. 
Opieka nad macierzyństwem, dziećmi i młodzieża w Rzeczypospolitej Polskiej, Warszawa 1928.

Oprawy, „Arkady” 1936, nr 5, s. 282-283.

[Reklama. J. Puget i S-wie], „Gazeta Przemysłowo-Rzemieślnicza” 1936, nr specjalny wydany łącznie z $\mathrm{nr} 8$, s. [76].

Sprawozdanie z dorocznego zebrania Sekcji Introligatorów w Warszawie, „Polska Gazeta Introligatorska" 1933, nr 5, s. 80.

Sprawozdanie z III. Kwartalnego zebrania Sekcji Introligatorów w Warszawie połaczonego z tradycyjnym opłatkiem, „Polska Gazeta Introligatorska” 1934, nr 2, s. 30.

Sprawozdanie z ogólnego zebrania Sekcji Introligatorów w Warszawie, „Polska Gazeta Introligatorska" 1933, nr 11, s. 174.

Sprawozdanie z rocznego sprawozdawczo-wyborczego zebrania Sekcji Introligatorskiej $w$ Warszawie, „Polska Gazeta Introligatorska” 1932, nr 4, s. 58.

Sprawozdanie z zebrania Sekcji Introligatorów (Oddział Warszawski), „Polska Gazeta Introligatorska" 1930, nr 5, s. 75.

Strajk introligatorów, „Wiadomości Graficzne” 1935, nr 12, s. 2.

(t), Nasze rzemiosła. Ankieta „, Gazety Porannej”. Polscy introligatorzy. (Rozmowa z panem W. Miernickim, starszym zgromadzenia introligatorów), „Gazeta Poranna” 1925, nr 117 , s. 7.

(W.K.), Oprawy introligatorskie pomystu Franciszka Seiferta, „Rzeczy Piękne” 1927, nr 1, s. 6-7.

Wystawa prac warsztatowych i zabytków cechowych, „Gazeta Przemysłowo-Rzemieślnicza" 1933, nr 7, s. 7-8.

Z życia Sekcji Introligatorów m.st. Warszawy, „Polska Gazeta Introligatorska” 1930, nr 10, s. 157.

Zarys historii cechów (Rzemiosła w Polsce), „Gazeta Przemysłowo-Rzemieślnicza” 1936, nr specjalny wydany łącznie z nr 8, s. 56-64.

Zbyszewski K., Kuźnia książki, „Przegląd Literacki” 1930, nr 5-6, s. 4-5.

Zjazd członków izb rzemieślniczych zawodu introligatorskiego w Warszawie, „Polska Gazeta Introligatorska" 1930, nr 7, s. 105-106.

Zjazd Mistrzów Introligatorskich w Poznaniu, „Polska Gazeta Introligatorska” 1929, nr 7, s. 81-84.

Zwycięstwo introligatorów warszawskich „Polska Gazeta Introligatorska” 1935, nr 13, s. 4.

Opracowania

Arct M., Jak powstaje książka, Warszawa 1929.

Czyżycki W., Introligatorstwo. Wskazówki techniczne, Warszawa 1948.

Dunin J., Okładka i obwoluta jako komunikat. Wprowadzenie do problematyki, [w:] Sztuka ksiązki. Historia - teoria - praktyka, red. M. Komza, Wrocław 2003, Acta Universitatis Wratislaviensis, t. 24, s. 81-90. 
Dunin J., Rozwój cech wydawniczych polskiej książki literackiej XIX-XX wieku, Łódź 1982, Acta Universitatis Lodziensis. Folia Scientiarum Artium et Librorum.

Hilchen M., Pomyślat, rysowat, wykonat Franciszek Joachim Radziszewski, [w:] Oprawy artystyczne Franciszka Joachima Radziszewskiego, Łódź 1987, s. nlb.

Łysiak W., Wyspa zaginionych skarbów, Chicago-Warszawa 2001.

Makowska H., Straus J., Sztuka polskiej książki literackiej 1918-1939. Katalog wystawy, Warszawa, maj-sierpień 1986, oprac. H. Makowska, J. Straus, Warszawa 1986.

Mravincsics S., Młody artysta introligator Władysław Grabowski, Poznań 1932.

Pokorzyńska E., „Proximus”. O szczególnie bliskich kontaktach introligatorów z klientami, [w: ] Introligatorzy i ich klienci, red. A. Wagner, Toruń 2017, s. 237-242.

Pokorzyńska E., Dzieje cechu introligatorskiego w Warszawie, „Acta Poligraphica” 2019, t. 19 , s. $45-79$.

Pokorzyńska E., Jan Recmanik 1874-1949. Artysta introligator, Bydgoszcz 2014.

Pokorzyńska E., Marcinkowski P., Zdzisław Szafranek (1906-1972), [w:] Żyja w naszej pamięci. Wspomnienia o pracownikach Biblioteki Publicznej m.st. Warszawy, wyd. 2, red. J. Myszkowska, Warszawa 2017, s. 100-104.

Pokorzyńska E., Zofia Dębicka - introligatorka z warszawskiej elity, „Roczniki Biblioteczne" 2015, t. 59, s. 73-90.

Rowiński S., Europejskość i polskość w oprawach wybitnych mistrzów pierwszej połowy XX wieku w Polsce. Reminiscencje warszawskie, [w:] Introligatorstwo warszawskie, Warszawa [2005], Sesje Varsavianistyczne, t. 15, s. 59-61.

Rypson P., Nie gęsi. Polskie projektowanie graficzne 1919-1949, Kraków 2011.

SKPK, Suplement, Warszawa 1986; SKPK, Suplement III, Warszawa 2010; SKPK, Suplement IV, Warszawa 2016.

Straus J., Cięcie. Fotomontaż na okładkach w międzywojennej Polsce, Warszawa 2014.

Tondel J., Okładki książek i czasopism z okresu Młodej Polski oraz międzywojnia od Wyspiańskiego do Strzemińskiego w Bibliotece Uniwersyteckiej w Toruniu, Toruń 2019.

Z dziejów rzemiosła warszawskiego, red. B. Grochulska, W. Pruss, Warszawa 1983. 
